\title{
Towards pesticide-free farming? Sharing needs and knowledge promotes Integrated Pest Management
}

\author{
Andrea Lucchi ${ }^{1} \cdot$ Giovanni Benelli ${ }^{1,2}$ (I) \\ Received: 3 January 2018 / Accepted: 2 April 2018 / Published online: 13 April 2018 \\ (C) Springer-Verlag GmbH Germany, part of Springer Nature 2018
}

\section{Introduction}

The overuse of chemical pesticides led to the fast-growing development of resistance in targeted insect pests, as well as to severe effects on non-target organisms and human health as well (Desneux et al. 2007; Benelli 2015, 2018a,b; Naqqash et al. 2016; Pavela and Benelli 2016; Guedes et al. 2016). In plant protection, a number of eco-friendly methods to manage insect pest populations have been developed with the aim to reduce the employ of synthetic pesticides (Gut et al. 2004; Millar 2007; Welter et al. 2005; Witzgall et al. 2010; Brockerhoff et al. 2012; Daane et al. 2012; Miller and Gut 2015). Unfortunately, they are still underused by a substantial number of Mediterranean stakeholders, due to lack of knowledge and trust. Indeed, farm managers are often aware of the existence of alternatives to pesticides. However, they do not know exactly the potency of a given mean or strategy and/or do not have full confidence in their effectiveness (Cooper et al. 2014). This can be partially due to a communication gap among researchers, policy makers, and farmers at country or regional level (Lamichhane et al. 2016).

In the USA, this gap is filled by the University Extension Services, which support farmers disseminating research-based information, to implement innovative methods for pests and diseases (Gadino 2012; Gadino et al. 2016). In recent years, the public Extension network experienced a fruitful cooperation with the private sector, encouraging and delivering effective and implementable solutions leading to substantial benefits to farmers (Krell et al. 2016). But what happen in

Responsible editor: Philippe Garrigues

Giovanni Benelli

benelli.giovanni@gmail.com

1 Department of Agriculture, Food and Environment, University of Pisa, via del Borghetto 80, 56124 Pisa, Italy

2 The BioRobotics Institute, Sant'Anna School of Advanced Studies, viale Rinaldo Piaggio 34, 56025 Pontedera, Pisa, Italy
European countries hosting important agricultural activities, like Italy? The scenario is patchy and confused. For instance, Trentino South Tyrol (Italy) hosts a good example of close cooperation between growers and research institutions, which allowed establishment of Integrated Pest Management (IPM) in the Region. Notably, the driving force for IPM implementation was the adoption in the last 20 years of the pheromonemediated mating disruption (MD), which strongly reduced insecticide use in that Region. MD has been applied from the 1990s with an area-wide approach against the codling moth and the leafrollers on apple crop, and against the vine moths in the vineyards (Ioriatti and Lucchi 2016). Although the mountainous terrain of the area was not optimal for the efficacy of MD, grower cooperatives and their field consultants were strongly influential in convincing growers to accept MD technology. Public research institutions conducted extensive research and education, and provided credible assessments of various MD formulations (Ioriatti et al. 2011, 2012). Thus, the development and adoption of area-wide mating disruption in Trentino-South Tyrol resulted from the merging of several favorable factors, which brought together researchers, advisors, cooperatives, growers, pheromone distributors, and related industries.

The results achieved in Trentino-South Tyrol have not been replicated in the rest of Italy, due in part to the lack of cooperation between research institutes, industry, and growers. On the other hand, some promising signals have been recently noted. Here, we focused on a fruitful cooperation between University and farms, which recently led-in less than 4 years - to the adoption of pesticide-free IPM approaches in about 1200 ha of highly valued Tuscan vineyards.

\section{What we are talking about: top-quality vineyards in the hearth of Tuscany}

We share facts and challenges arising from a recent cooperative pilot experience carried out in the wine growing area of 
Bolgheri (coastal Tuscany, DMS: 43.233982, 10.614802), one of Italy's most prestigious areas for the production of top-quality and high economic value wines, mainly produced from Cabernet Sauvignon, Cabernet franc, and Merlot cultivars (http://www.wine-searcher.com/regions-bolgheri) (Fig. 1). The Bolgheri area is characterized by sandy soils and mild climate with medium-high rainfall $(400-800 \mathrm{~mm}$ per year on average).

\section{Issues to watch for}

The highly valued Bolgheri vineyards have historically been affected by heavy infestations of two key pests, the European grapevine moth (EGVM), Lobesia botrana (Denis \& Schiffermüller) (Lepidoptera: Tortricidae) (Fig. 2) and the vine mealybug (VMB), Planococcus ficus Signoret (Hemiptera: Pseudococcidae) (Fig. 3).

Insecticide strategies generally adopted by growers included two or three sprayings per year against EGVM with insect growth regulators or organophosphorates, and 1-2 treatments per year against VMB with chitin-synthesis inhibitors or neurotoxic insecticides, leading to detrimental consequences on non-target species and the environment. Recently, one famous winery located in Bolgheri (Guado al Tasso, Marchesi Antinori $\left.{ }^{\circledR}\right)$ asked University for help to manage insect pest outbreaks. Indeed, insecticides have been showing limited efficacy in the previous years, so that the winery manager would like to start adopting alternative and more sustainable strategies.

\section{Best practices and possible solutions to manage insect pests}

On our proposal, the farm firstly applied the pheromonemediated mating disruption (MD) in late March 2014 against L. botrana on one sixth (50 ha) of the whole farm surface, to be able to compare obtained results with the conventional

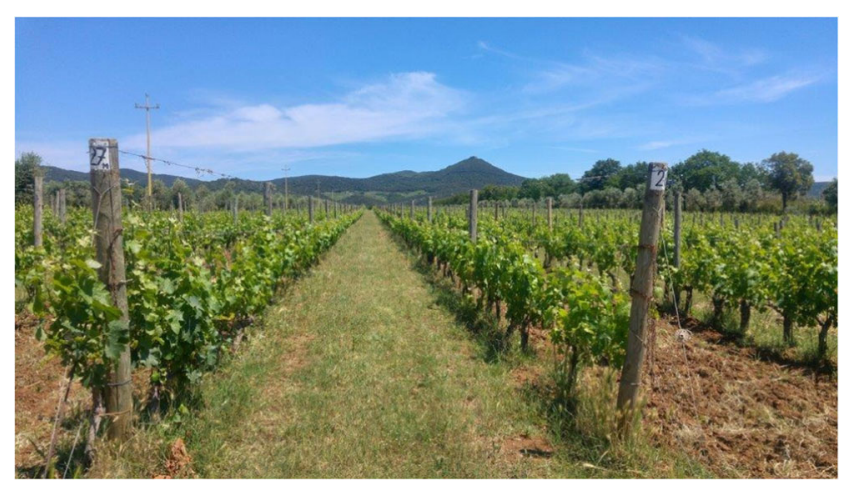

Fig. 1 Highly valued vineyards in the Bolgheri wine growing area (Tuscany, Italy)
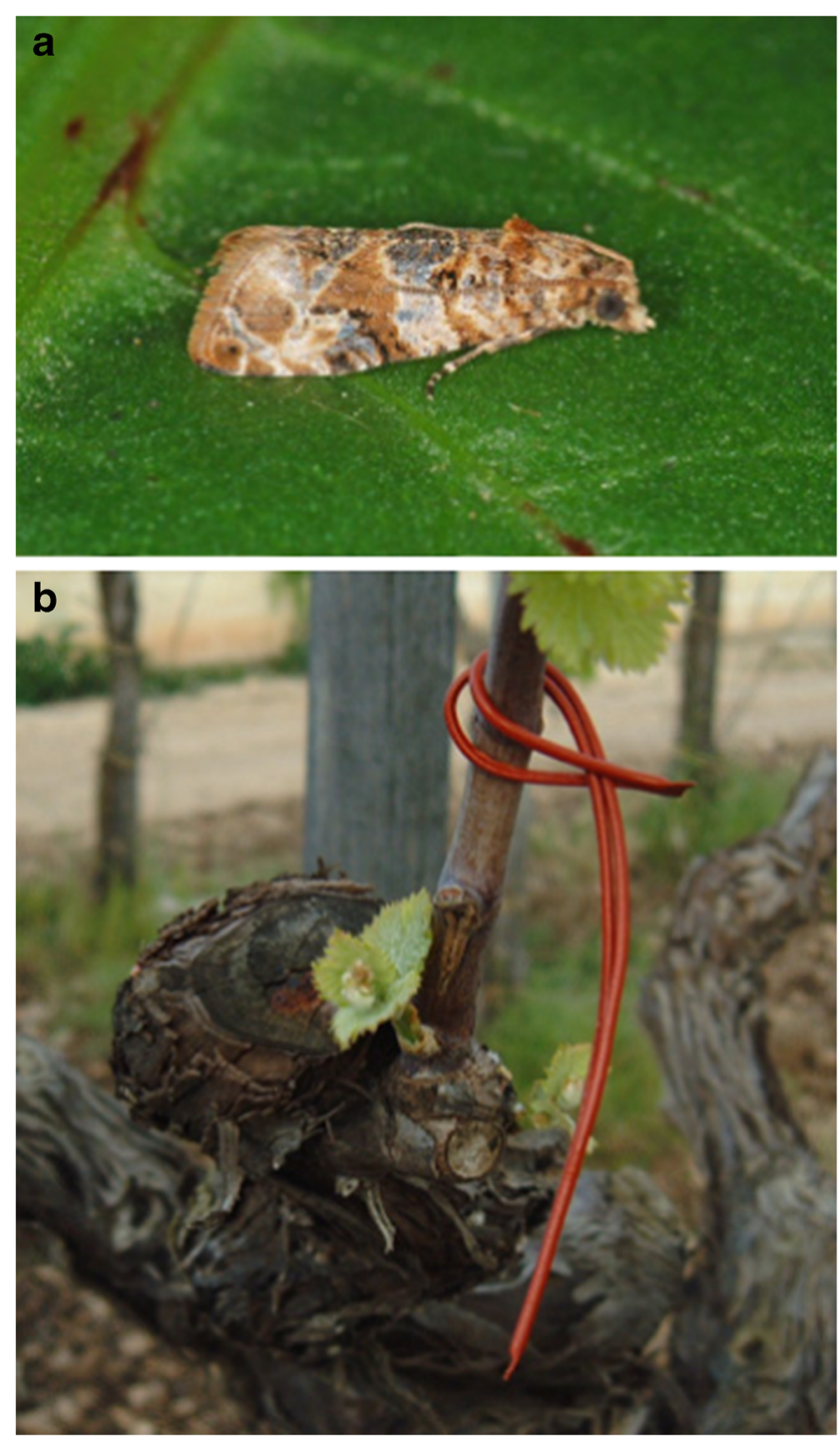

Fig. 2 Highly valued vineyards of coastal Tuscany are severely affected by a the European grapevine moth, Lobesia botrana (Denis \& Schiffermüller) (Lepidoptera: Tortricidae). In 2016, this moth pest has been controlled in more than 1200 ha relying to a pheromone-mediated mating disruption approach; here, $\mathbf{b}$ a sex pheromone dispenser (Isonet ${ }^{\circledR}$ L TT, Shin-Etsu) releasing (7E,9Z)-7,9-dodecadien-1-yl acetate during mating disruption programs carried out in Tuscany against $L$. botrana

insecticide strategy. MD was applied with Shin-Etsu Isonet LTT ${ }^{\circledR}$ dispensers (Fig. 2) at a rate of 250 units/ha. The control strategy to manage $P$. ficus populations included the release of two biological control agents (BCAs), the encyrtid parasitoid Anagyrus sp. near pseudococci (Girault) in May (1000 insects/ha on a total of $3.5 \mathrm{ha}$ ) and the coccinellid predator Cryptolaemus montrouzieri Mulsant (500 insects/ha on a total of 4 ha) in June and/or July (Fig. 3).

From the beginning, the management of the program was in the hands of a technical working group (TWG) composed by University of Pisa applied entomologists and winery technicians. The monitoring of pest populations was carried out with pheromone traps and cluster sampling. Field assessments 

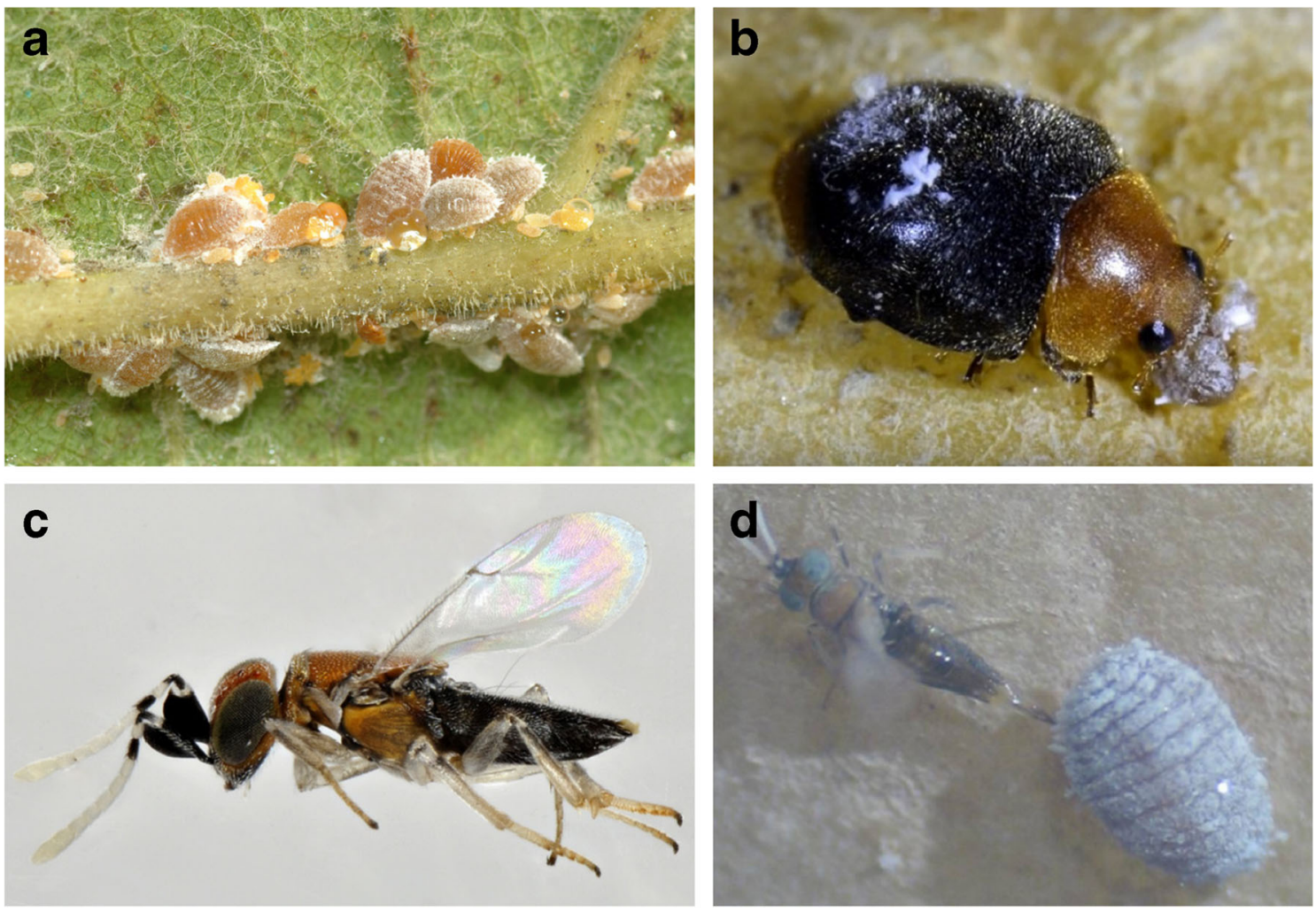

Fig. 3 a The vine mealybug, Planococcus ficus Signoret (Hemiptera: Pseudococcidae), is another key pest in Tuscan coastal vineyards. Biological control agents used to control vine mealybug populations

were conducted both in MD and conventional vineyards regarding EGVM and in the plots where biocontrol agents were released. Since a frequent knowledge gap for IPM practitioners has been earlier detected concerning natural enemies and their function in these agroecosystems (Jones et al. 2009), the field release of vineyard biocontrol agents was preceded by interactive workshops and hands-on field day activities carried out by University personnel with local farmers and agronomists, with the main aim to learn how to monitor pest populations, as well as how recognize and protect beneficial arthropods in vineyards.

To assess the effectiveness of MD against $L$. botrana, we considered $(a)$ the number of male captures per pheromone trap (Trap Test Isagro®) per week as well as $(b)$ the rate of infested bunches and number of nests per inflorescence (first generation), or number of larvae per bunch and number of damaged berries per bunch (second and third generation). First- and second-generation infestation was measured through on-site surveys on non-destructively sampled inflorescences and clusters. As to the third generation, an estimate of the larval population and the grape infestation was made at harvest, on samples collected in the vineyards and dissected in the laboratory (Lucchi et al. 2018). As for VMB populations, the effectiveness of biocontrol agents was assessed in midJuly and at harvest by checking $A$. sp. near pseudococci included ladybug predators, such as b Cryptolaemus montrouzieri Mulsant, as well as Anagyrus sp. near pseudococci (Girault) parasitoids, here $\mathbf{c}$ a female $\mathbf{d}$ parasitizing a mealybug

parasitization rate in mid-July and at harvest, and estimating the abundance of $C$. montrouzieri larvae and adults in the VMB colonies. Field efficacy assessment led to the analysis of more than 20,000 grapes during the overall growing season.

Results were very promising; the farmers did not spray against $L$. botrana in MD areas, with extremely low infestation at harvest (less than 5\% of infested bunches) (Lucchi et al. 2018), whereas they sprayed two times in the conventional areas, with a more limited efficacy. Besides, excellent results were obtained in the control of VMB, so that other local farms joined the project. MD was then applied on about 300 ha in 2015 , and biocontrol agents were efficiently released in new plots for a total of about 20 ha with positive results.

Therefore, the following year (2016) other farms joined the project. MD was applied on 700 ha in the Bolgheri area and biocontrol agents were released on 200 ha. The substantial decrease in the amount of insecticides due to MD and biocontrol agents use was perceived as the first major step forward, which improved the public perception that wine was produced with high environmental safety standards. The action plan drastically reduced insect populations, so that other farms joined the program and the area managed in IPM further raised in 2017 (biocontrol agents on 800 ha and MD on more than 1200 ha). 
The economic evaluation of biological vs. chemical control strategies to manage EGVM and VMB is presented in Tables 1 and 2. Estimates have been done considering current routine choices by the agronomists of Guado al Tasso, Marchesi Antinori ${ }^{\circledR}$ (Table 1) and another top-quality Tuscan wine producer in Bolgheri (Table 2). Table 1 shows a pronounced difference between chemical and biological control strategies carried out in the top-quality farm Guado al Tasso, Marchesi Antinori ${ }^{\circledR}$, where two insecticide-based treatments per insect pest are usually carried out in vineyards managed with chemical control, without the presence of work for hire, leading to a final cost of $219.16 €$ over the $417.00 €$ of biological control (Table 1). However, costs may vary consistently according to the routine choice for pest management in the studied farms. In Table 2, the cost of biological control is still higher if compared to chemical control (435.75 vs. $357.00 € / \mathrm{ha}$ ), while a further difference of about 130 euros/ ha is experienced if a $B$. thuringiensis-based treatment is required during the grape growing season. This difference is mostly due to the high cost of work for hire needed for insecticidal treatments.

Very recently, the fruitful cooperation between University of Pisa applied entomologists, farms, and winemakers continued with a Tuscan regional project PIF "Artisans of Tuscan wine" funded by EU through Regione Toscana (PSR 20142020). The project was funded for an overall budget of about 4 million euros, of which more than 220,000 euros have been devoted to the action 16.2 named "Introduction and evaluation of biological control techniques for an effective and sustainable control of vineyard insect pests in Tuscany." This action was aimed to improving the grapevine quality and reducing costs, through the reduction of EGVM and P. ficus infestations using control tools with minimal environmental impact. A major focus was dedicated to the understanding of natural enemy biology in Tuscan vineyards, as well as to shed light on the efficacy of pesticide-free control approaches, such as MD against L. botrana. The final aim was to transfer new information, encouraging decision-makers adopting more practices to conserve natural enemies and boost good IPM practices.

In agreement with the criteria recently summarized by Gadino et al. (2016), the goals outlined above have been reached through technology transfer activities directly carried out in the field by the University personnel, as well as interactive workshops dedicated to update farmers with novel strategies, including the employ of selected biocontrol agents and/ or MD approaches (Fig. 4). In the last 2 years, the technology transfer activities conducted in the field led to the training of more than 50 operators (i.e., 4 or more per farm), who are still active as skilled personnel monitoring vineyard pests, to ensure a timely and effective approach when applying control strategies. Furthermore, more than 200 farmers and winemakers participated to the technology transfer meetings, conducted in various locations on the Tuscan coast during the whole project duration. Besides interactive workshops, handson field day activities were carried out by University applied entomologists with the decision-makers during the whole grapevine growing season (i.e., 7 days per month, from early April to late September, in various Tuscan farms joining BIOCONVITO), along with lectures and presentations (i.e., $>30$ events during the project, with a total of more than 200 participants), print articles and posters (more than 10 items published during the project and discussed with decision makers) and online media shared by University of Pisa (e.g., https://www.youtube.com/watch?v=ILa2ZawSBHc\&t=2s) were used to train farmers and agronomists to recognize,

Table 1 Economic evaluation of biological vs. chemical control strategies considering routine choices by the agronomists of Guado al Tasso, Marchesi Antinori® (Bolgheri, Tuscany) to manage the European grapevine moth and the vine mealybug

\begin{tabular}{|c|c|c|c|c|}
\hline Pest management strategy & Description & $\begin{array}{l}\text { No. of } \\
\text { treatments }\end{array}$ & Cost $€ /$ ha & Notes \\
\hline \multirow[t]{6}{*}{ Biological control } & EGVM MD dispenser Isonet® L TT 250 (Shin-Etsu) & 1 & $110.00 €$ & 250 dispensers Isonet L TT/ha \\
\hline & Deployment of the MD dispensers in the field & 1 & $28.00 €$ & - \\
\hline & Anagyrus sp. near pseudococci (Bioplanet $®$, VMB parasitoid) & 1 & $130.00 €$ & 1000 parasitoids/ha \\
\hline & Cryptolaemus montrouzieri (Bioplanet $®$, VMB predator) & 1 & $135.00 €$ & 500 beetles/ha \\
\hline & BCA field release & 2 & $14.00 €$ & $7 € /$ ha per each BCA release \\
\hline & Total & & $417.00 €$ & - \\
\hline \multirow[t]{6}{*}{ Chemical control } & Spirotetramat (Movento®, Bayer) against VMB & 1 & $50.00 €$ & - \\
\hline & Chlorpyrifos-methyl (Reldan $®$, Dow AgroSciences) against VMB & 1 & $16.00 €$ & - \\
\hline & Chlorantraniliprole (Coragen $®$, DuPont) against EGVM & 1 & $40.00 €$ & - \\
\hline & Metoxifenozide (Prodigy®, Bayer) & 1 & $33.00 €$ & - \\
\hline & Cost of insecticide-based treatment/ha & 4 & $80.16 €$ & $20.04 € /$ ha per each treatment \\
\hline & Total & - & $219.16 €$ & - \\
\hline
\end{tabular}

BCA biological control agents; EGVM European grapevine moth, Lobesia botrana; MD mating disruption; VMB vine mealybug, Planococcus ficus 
Table 2 Economic evaluation of biological vs. chemical control strategies to manage two major insect pests damaging Tuscan vineyards, the European grapevine moth [Lobesia botrana (Denis \&
Schiffermüller)] and the vine mealybug (Planococcus ficus Signoret). The estimate has been done considering routine choices by the agronomists of another top-quality Tuscan farm in Bolgheri

\begin{tabular}{|c|c|c|c|c|}
\hline $\begin{array}{l}\text { Pest management } \\
\text { strategy }\end{array}$ & Description & $\begin{array}{l}\text { No. of } \\
\text { treatments }\end{array}$ & $\begin{array}{l}\text { Cost } \\
€ / \text { ha }\end{array}$ & Notes \\
\hline \multirow[t]{9}{*}{ Biological control } & EGVM MD dispenser Isonet® L TT 250 (Shin-Etsu) & 1 & $110.00 €$ & 250 dispensers Isonet $\mathrm{L}$ TT/ha \\
\hline & Deployment of the MD dispensers in the field & 1 & $27.00 €$ & $\begin{array}{l}1.8 \mathrm{~h} / \mathrm{ha}=\text { mean value for } \\
\text { dispenser } \\
\text { deployment in } 2017\end{array}$ \\
\hline & Anagyrus sp. near pseudococci (Bioplanet ${ }^{\circledR}, \mathrm{VMB}$ parasitoid) & 1 & $130.00 €$ & 1000 parasitoids/ha \\
\hline & Cryptolaemus montrouzieri (Bioplanet ${ }^{\circledR}, \mathrm{VMB}$ predator) & 1 & $135.00 €$ & 500 beetles/ha \\
\hline & BCA field release & 2 & $15.00 €$ & $7.50 € /$ ha per each $\mathrm{BCA}$ release \\
\hline & Bacillus thuringiensis kurstaki (Delfin $®$ Dupont) against EGVM & 1 & $18.75 €$ & $\begin{array}{l}\text { Only with EGVM infestation > } \\
\text { than the established threshold } \\
(5 \%)\end{array}$ \\
\hline & $\begin{array}{l}\text { Cost of B. thuringiensis kurstaki-based treatment/ha (work for } \\
\text { hire) }\end{array}$ & 1 & $130.00 €$ & $\begin{array}{l}\text { Only with EGVM infestation > } \\
\text { than the established threshold } \\
(5 \%)\end{array}$ \\
\hline & $\begin{array}{l}\text { Total option } 1 \text { (only BCA and MD, without } B \text {. thuringiensis } \\
\text { kurstaki-based treatment) }\end{array}$ & - & $435.75 €$ & - \\
\hline & $\begin{array}{l}\text { Total option } 2 \text { (if the } B \text {. thuringiensis kurstaki-based } \\
\text { treatment is needed) }\end{array}$ & - & $565.75 €$ & - \\
\hline \multirow[t]{4}{*}{ Chemical control } & Spirotetramat (Movento®, Bayer) against VMB & 1 & $64.00 €$ & - \\
\hline & $\begin{array}{l}\text { Chlorpyrifos-methyl (Reldan }{ }^{\circledR} \text {, Dow AgroSciences) against } \\
\text { EGVM }\end{array}$ & 1 & $33.00 €$ & - \\
\hline & Cost of insecticide-based treatment/ha (work for hire) & 2 & $260.00 €$ & $\begin{array}{l}130.00 € / \text { ha per each treatment } \\
\text { (work for hire) }\end{array}$ \\
\hline & Total & - & $357.00 €$ & - \\
\hline
\end{tabular}

BCA biological control agents; EGVM European grapevine moth, Lobesia botrana; MD mating disruption; VMB vine mealybug, Planococcus ficus

monitor, and promote the populations of biological control agents, as well as to monitor pest population abundance (Fig. 4). As earlier stressed out by Gadino et al. (2016), the results of BIOCONVITO are fully available to farmers and agronomists on the project website (http://www.bioconvito.it/).

One may argue that results reported here promoted IPM only at regional scale. However, this is not the case. Indeed, the approach followed here by top-quality Tuscan grapevine producers has been highlighted at European Union level within the meetings of EIP-AGRI Focus Group (FG) on diseases and pests in viticulture.

\section{Keys of success, future challenges, and lesson learned}

Currently, more than 249,000 ha of vineyards is managed using MD against EGVM in Europe, with about 76,000, $60,000,47,000$, and 36,000 ha in Spain, Germany, France, and Italy, respectively. Based on the experience in Italy described above, we identified several key factors leading to the operational success of the proposed approaches. First, sharing the problem: the limited efficacy of insecticides pushed growers to look for alternative and more sustainable strategies. Second, the cultural conditions: vineyards were relatively young and well managed. Third, the involved Tuscan growers and technicians were well trained and open to new experiences. Fourth, the University's support has been revealed as crucial to the success of the program.

Decision-makers particularly appreciated hands-on field activities aimed to learn how pests can be monitored and how biocontrol agent populations can be protected and promoted. In this framework, a major future challenge will be find dedicated funds to build interactive online course where participants can be constantly updated with novel technology transfer knowledge, as well as perform field simulations about how to correctly set an MD- or biocontrol agent-based pest management strategy. In addition, new proposal at national and EU level are ongoing to receive funds for area-wide natural enemy monitoring projects, and creation of a smartphone or tablet accessible field guide for common Tuscan vineyard pests and related biocontrol agents (see also Gadino et al. 2016). Notably, area-wide pest and biocontrol agent data collected by farmers during the grapevine growing season can be used to develop online databases helping decision-makers to do their IPM choices, predicting pest populations and 

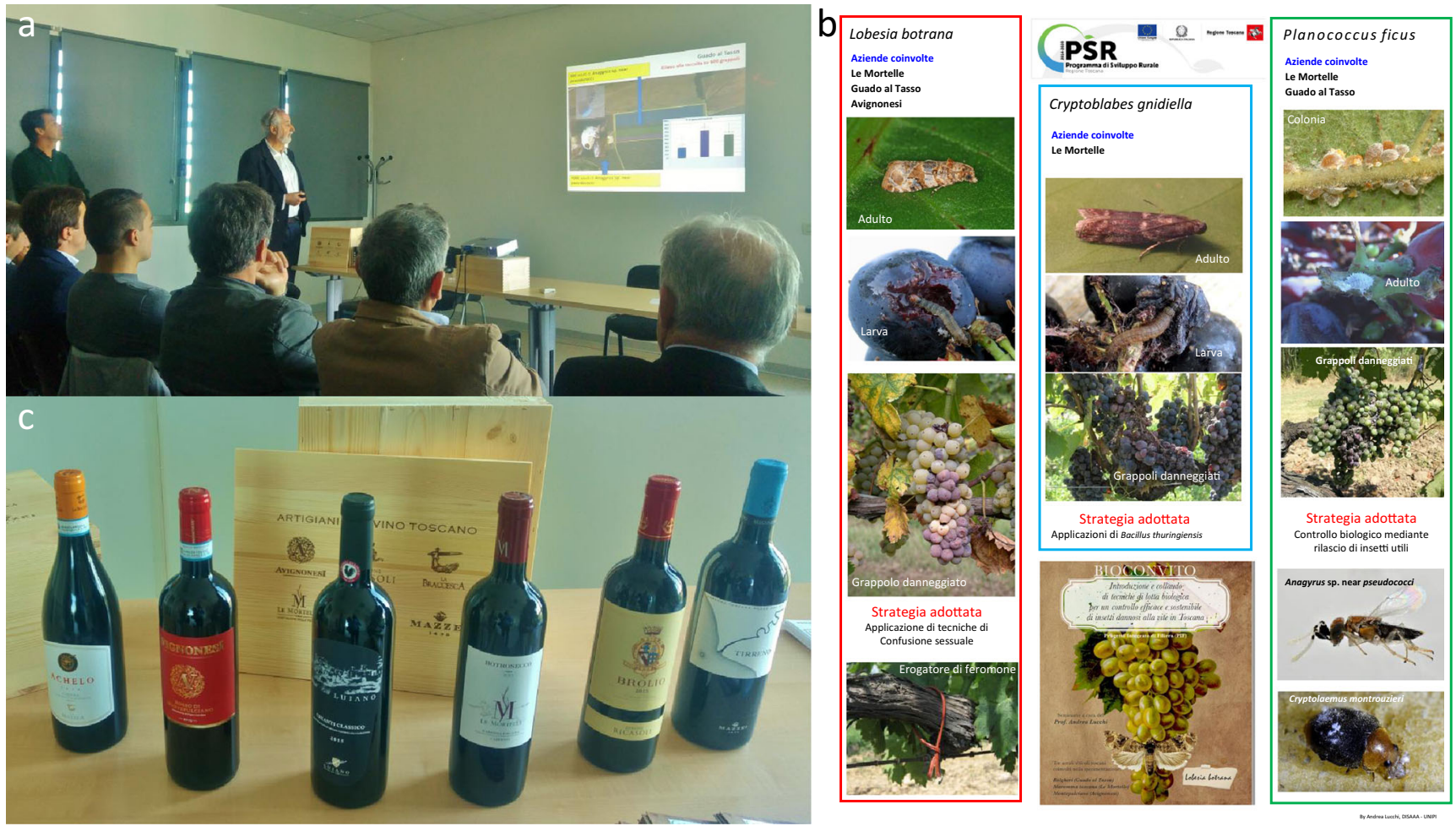

Fig. 4 A wide number of farmers and winemakers participated to a the technology transfer meetings conducted during the Tuscan regional project PIF "Artisans of Tuscan wine" (action 16.2 BIOCONVITO) funded by EU through Regione Toscana (PSR 2014-2020). Besides, b posters and articles summarizing novel concepts and technologies for the

outbreaks, allowing comparisons between growing sites over time. In addition, from a scientific point of view, these data contribute to the so-called eco-informatics approaches, being developed in several cropping systems (Michener and Jones 2012; Rosenheim and Meisner 2013). Besides, several comparable attempts on how to manage IPM decision in other cropping systems have been recently proposed for various herbaceous crops, including wheat (EuroWheat, www. eurowheat.au.dk) (Lamichhane et al. 2016).

Overall, as a take-home message, we believe that no insurmountable obstacles would prevent substantial increases in IPM implementation in Italian vineyards, if interest among research scientists in promoting and transferring existing knowledge can be cultivated. Scientists must play a leading role in engaging all groups of stakeholders to work together with a common goal, which probably has been the most important factor in the success achieved in the project discussed above. The final aim of the present approach for pesticide-free management of vineyard pests is to boost a synergistic publicprivate cooperation, in a comparable manner to that recently experienced by USA Extension services and private partners (Krell et al. 2016), allowing decision-makers to receive a continuously updated and balanced pest management knowledge, to help them in managing their grows, with substantial benefits for human health and the environment. eco-friendly control of the European grapevine moth [Lobesia botrana (Denis \& Schiffermüller)] and the vine mealybug (Planococcus ficus Signoret) were shared among decision makers. c A celebrative collection of top-quality Tuscan wines produced by farms under the project PIF "Artisans of Tuscan wine" (PSR 2014-2020)

Acknowledgements Five anonymous reviewers kindly improved an earlier version of the present Trends Editorial. We greatly appreciated the cooperation of the farms Guado al Tasso, Marchesi Antinori (Bolgheri), Le Mortelle (Castiglione della Pescaia), and Ornellaia (Bolgheri).

Funding The technology transfer activity summarized in this Trends Editorial was partially funded by EU-Regione Toscana project "Artisans of Tuscan Wine" (action 16.2, acronym "BIOCONVITO," PSR 2014-2020).

\section{Compliance with ethical standards}

Conflict of interest The authors declare that they have no competing interests.

Disclaimer The mention of trade names or commercial products in this publication does not imply recommendation or endorsement by the University of Pisa and Sant'Anna School of Advanced Studies.

\section{References}

Benelli G (2015) Research in mosquito control: current challenges for a brighter future. Parasitol Res 114:2801-2805

Benelli G (2018a) Plant-borne compounds and nanoparticles: challenges for medicine, parasitology and entomology-GREEN-NANOPEST\&DRUGS. Environ Sci Poll Res doi. https://doi.org/10.1007/ s11356-017-9960-y 
Benelli G (2018b) Gold nanoparticles — against parasites and insect vectors. Acta Trop 178:73-80

Brockerhoff EG, Suckling DM, Kimberley M, Richardson B, Coker G, Gous S, Kerr JL, Cowan DM, Lance DR, Strand T, Zhang A (2012) Aerial application of pheromones for mating disruption of an invasive moth as a potential eradication tool. PLoS One 7(8):e43767. https://doi.org/10.1371/journal.pone.0043767

Cooper M, Varela LG, Smith RJ, Whitmer DR, Simmons GA, Lucchi A, Broadway R, Steinhauer R (2014) Growers, scientists and regulators collaborate on European grapevine moth program. Calif Agric 4: $125-133$

Daane KM, Almeida RP, Bell VA, Walker JT, Botton M, Fallahzadeh M, et al. (2012) Biology and management of mealybugs in vineyards. In: Arthropod Management in Vineyards: (pp. 271-307). Springer Netherlands

Desneux N, Decourtye A, Delpuech JM (2007) The sublethal effects of pesticides on beneficial arthropods. Annu Rev Entomol 52:81-106

Gadino AN (2012) Summary: audience "clicker" surveys - perspectives of North Central Washington apple growers and consultants. http:// www.enhancedbiocontrol.com

Gadino AN, Brunner JF, Chambers U, Jones WE, Castagnoli S, Jones VP (2016) A perspective on the extension of research-based information to orchard management decision-makers: lessons learned and potential future directions. Biol Control 102:121-127

Guedes RNC, Smagghe G, Stark JD, Desneux N (2016) Pesticideinduced stress in arthropod pests for optimized integrated pest management programs. Annu Rev Entomol 61:43-62

Gut LJ, Stelinski LL, Thomson DR, Miller JR (2004) Behaviourmodifying chemicals: prospects and constraints in IPM. In: Integrated pest management: potential, constraints, and challenges. Dhaliwal and Cuperus, CABI Publishing, Cambridge, MA, Eds. Koul, pp 73-121

Ioriatti C, Lucchi A (2016) Semiochemical strategies for tortricid moth control in apple orchards and vineyards in Italy. J Chem Ecol 42(7): $571-583$

Ioriatti C, Anfora G, Tasin M, De Cristofaro A, Witzgall P, Lucchi A (2011) Chemical ecology and management of Lobesia botrana (Lepidoptera: Tortricidae). J Econ Entomol 104(4):1125-1113

Ioriatti C, Lucchi A, Varela L G (2012) Grape berry moths in western European vineyards and their recent movement into the new world.
In Bostanian NJ et al (eds) Arthropod management in vineyards: pests, approaches, and future directions. Springer Science + Business Media B.V. https://doi.org/10.1007/978-94-007-4032-7_ 14

Jones VP, Unruh TR, Horton DR, Mills NJ, Brunner JF, Beers EH, Shearer PW (2009) Tree fruit IPM programs in the western United States: the challenge of enhancing biological control through intensive management. Pest Manag Sci 65(12):1305-1310

Krell RK, Fisher ML, Steffey KL (2016) A proposal for public and private partnership in extension. J Integr Pest Manag 7(1):4

Lamichhane JR, Aubertot JN, Begg G, Birch ANE, Boonekamp P, Dachbrodt-Saaydeh S, Hansen JG, Hovmøller MS, Jensen JE, Jørgensen LN, Kiss J, Kudsk P, Moonen AC, Rasplus JY, Sattin M, Streito JC, Messéan A (2016) Networking of integrated pest management: a powerful approach to address common challenges in agriculture. Crop Prot 89:139-151

Lucchi A, Ladurner E, Iodice A, Savino F, Ricciardi R, Cosci F, Conte G, Benelli G (2018) Eco-friendly pheromone dispensers - a green route to manage the European grapevine moth? Environ Sci Poll Res. https://doi.org/10.1007/s11356-018-1248-3

Michener WK, Jones MB (2012) Ecoinformatics: supporting ecology as a data-intensive science. Trends Ecol Evol 27:85-93

Millar JG (2007) Insect pheromones for integrated pest management: promise versus reality. Redia 90:51-55

Miller JR, Gut LJ (2015) Mating disruption for the 21st century: matching technology with mechanism. Environ Entomol 44(3):427-453

Naqqash MN, Gökçe A, Bakhsh A, Salim M (2016) Insecticide resistance and its molecular basis in urban insect pests. Parasitol Res 115: 1363-1373

Pavela R, Benelli G (2016) Essential oils as eco-friendly biopesticides? Challenges and constraints. Trends Plant Sci 21:1000-1007

Rosenheim JA, Meisner MH (2013) Ecoinformatics can reveal yield gaps associated with crop-pest interactions: a proof-of-concept. PLoS One doi 8:e80518. https://doi.org/10.1371/journal.pone.0080518

Welter S, Pickel C, Millar J, Cave F, Van Steenwyk R, Dunley J (2005) Pheromone mating disruption offers selective management options for key pests. Calif Agric 59(1):16-22

Witzgall P, Kirsch P, Cork A (2010) Sex pheromones and their impact on pest management. J Chem Ecol 36(1):80-100 